Syntax Literate: Jurnal Ilmiah Indonesia p-ISSN: 2541-0849

e-ISSN: 2548-1398

Vol. 7, No. 1, Januari 2022

\title{
ANALISIS KLASTERING UNTUK PENILAIAN KEMUNGKINAN KERJA SAMA PERUSAHAAN ASURANSI JIWA
}

\section{Titiek Irewati}

Universitas Gunadarma, Indonesia

Email: titiekirewati2@gmail.com

\begin{abstract}
Abstrak
Kerja sama merupakan suatu bentuk strategi yang mutakhir dilaksanakan oleh perusahaan perusahaan asuransi jiwa di Indonesia. Adanya kerja sama memungkinkan pengaliran sumber daya yang dapat memperkuat perusahaan dalam pencapaian kinerja. Penelitian ini untuk mengetahui bagaimana pengelompokan antar perusahaan-perusahaan asuransi jiwa di Indonesia. Pengelompokan atau sistem partisi himpunan secara matematis merupakan cara untuk melihat peluang terjadinya kerja sama antar perusahaan. Pada 40 perusahaan asuransi jiwa di Indonesia, berdasarkan variabel asset, investasi, modal, laba, premi brutto, dan hutang, diuji dengan analisis multivariate klaster metode hirarki. Hasil analisis menunjukkan perusahaan perusahaan tersebut terbagi dalam tiga kelompok locus atau posisi yaitu: Locus A sebanyak 36 perusahaan, Locus B sebanyak 3 perusahaan dan Locus $\mathrm{C}$ sebanyak 1 perusahaan. Hal ini menunjukkan kondisi kondisi perusahaan asuransi jiwa Indonesia cenderung bertumpu pada satu locus, yaitu bersifat lebih homogen.
\end{abstract}

Kata Kunci: klaster; kerja sama; asuransi jiwa

\section{Abstract}

Cooperation is a form of sophisticated strategy implemented by life insurance companies in Indonesia. The existence of cooperation allows the flow of resources that can strengthen the company in achieving performance. This research is to find out how the grouping between life insurance companies in Indonesia. Grouping or system partitioning sets mathematically is a way to see the opportunity for cooperation between companies. In 40 life insurance companies in Indonesia, based on variable assets, investments, capital, profits, brutto premiums, and debt, tested with multivariate analysis of hierarchical cluster methods. The results of the analysis showed that the company was divided into three groups of locus or positions, namely: Locus $A$ as many as 36 companies, Locus $B$ as many as 3 companies and Locus $C$ as many as 1 company. This shows the condition of indonesian life insurance companies tends to rely on one locus, which is more homogeneous.

Keywords: cluster; cooperation; life insurance

\begin{tabular}{|c|c|}
\hline How to cite: & $\begin{array}{l}\text { Irewati. T (2022) Analisis Klastering Untuk Penilaian Kemungkinan Kerja Sama Perusahaan Asuransi } \\
\text { Jiwa. Syntax Literate: Jurnal Ilmiah Indonesia, 7(1). http://dx.doi.org/10.36418/ Syntax- } \\
\text { Literate.v7i1.6065 }\end{array}$ \\
\hline E-ISS & $2548-1398$ \\
\hline Published by: & Ridwan Institute \\
\hline
\end{tabular}


Titiek Irewati

Received: 2021-12-20; Accepted: 2022-01-05; Published: 2022-01-15

\section{Pendahuluan}

Setiap perusahaan atau organisasi senantiasa ingin untuk dapat bertahan lama atau terus ada. Hal ini menjadi tolok ukur kesuksesan suatu usaha. Upaya pencapaian tujuan perusahaan tersebut membuat para manajemen perusahaan harus mampu mengintegrasikan secara efektif segala sumber daya yang dipunyai dan beradaptasi dengan kondisi eksternal yang mengelilinginya (David, Ali, \& Al-Aali, 2009). Pemanfaatan optimal semua sumber daya perusahaan merupakan suatu cara bagi perusahaan untuk memperoleh keunggulan bersaing. Strategi bersaing merupakan suatu bentuk pemanfaatan efektif segala sumber daya perusahaan.

Pada saat ini, sumber daya perusahaan tidak hanya terdiri dari kapital, sumber daya manusia dan teknologi tetapi juga menyangkut sumber daya relasi yaitu kemampuan bekerja sama dengan perusahaan lain. Sumber daya relasi merupakan landasan bagi pembentukan posisi bersaing yang mantap. Adanya keterbatasan jenis dan jumlah sumber daya yang dimiliki membuat perusahaan berusaha memperoleh sumber daya yang diperlukan dengan memanfaatkan sumber daya relasi yang dipunyai. Suatu strategi yang dijalankan perusahaan adalah dengan mengadakan kerja sama antar perusahaan, baik sejenis industri ataupun berlainan industri. Kerja sama strategis umumnya didefinisikan sebagai perjanjian antar perusahaan yang menyangkut sistem pertukaran atau pakai bersama berbagai ragam sumber daya dan aset tertentu (Gulati, 1999). Adanya relasimenjadi dasar bagi suatu pembentukan jaringan yang berkaitan dengan kondisi nyata pasar: konsumen dan para pelaku yang ada dalam industri tersebut. Jaringan kerja tempat suatu perusahaan berelasi antar sesama dianggap sebagai sumber daya eksternal. Berdasarkan jaringan kerja tersebut, perusahaan dapat merumuskan kegiatan strategis yang pada akhirnya dapat meningkatkan kinerja perusahaan (Muller \& Peres, 2019).

Konsep pengelompokan atau klastering dalam jaringan industri telah banyak dipergunakan dalam dunia ekonomi untuk memperlihatkan konsep aglomerasi dan spesialisasi. Observasi mengenai klaster jaringan industry dapat memperlihatkan karakteristik dunia mini. (Feser \& Bergman, 2000) menyatakan konsep klastering secara ekonomi praktis adalah pengelompokan perusahaan-perusahaan yang saling berhubungan berdasarkan satu atau lebih dimensi ini: keterkaitan input output, buyer supplier, posisi atau lokasi geografis dan adanya kerjasama dalam kompetisi. Adanya pengelompokan atau klastering akan memungkinkan terjadinya pengamatan dan penelaahan lebih mendalam untuk mengetahui serta memahami karakteristik perusahaan dan dinamika industri.

Pengetahuan mengenai kemampuan klastering suatu perusahaan akan memudahkan kita untuk menilai bagaimana aliran pertukaran informasi, pengetahuan serta kerja sama antar perusahaan. Adanya interaksi sosial yang dipunyai perusahaan dengan konsumen / nasabah, rekanan dan lembaga penelitian memungkinkan perusahaan memperoleh peluang untuk mendapatkan interaksi yang lebih kuat dengan 
berbagai pelaku industri. Klaster atau pengelompokan industri dianggap sebagai suatu jenis tertentu struktur sosial sehingga penelitian lebih lanjut mengenai hubungan di dalam struktur menjadi sangat relevan.

Perusahaan asuransi jiwa merupakan perusahaan yang bergerak di bidang jasa proteksi atau perlindungan terhadap kerugian keuanga yan diakibatkan oleh kematian, cacat dan penuaan biologis. Perusahaan asuransi berusaha menanggung risiko dari peristiwa (event) yang menimbulkan bahaya/peril yaitu yang dapat menimbulkan kerugian/kerusakan terhadap kepentingan (interest) yang diasuransikan. Perusahaan asuransi jiwa secara spesifik mempunyai ciri dan tujuan operasional yang khas untuk mencapai sasarannya. Perusahaan harus mampu mengusahakan kesediaan masyarakat untuk bersedia bergabung dengannya dalam rangka menghadapi risiko yang mungkin terjadi pada kehidupan manusia. Sejak masa penjajahan Belanda, usaha asuransi jiwa telah bergerak di Indonesia dengan adanya pendirian Nederlandsche Indische Levenverzekering en Lifrente Maatschappj (NILM) pada tahun 1859 di Batavia. Pada perjalanan waktu selanjutnya akhirnya banyak perusahaan asuransi jiwa yang beroperasi di Indonesia. Pada tahun 1986, sebanyak 20 perusahaan berkegiatan di Indonesia. Deregulasi mengenai perusahaan jasa keuangan pada tahun 1988 membuka terjadinya kemudahan bagi pendirian dan operasi perusahaan asuransi jiwa. Pada tahun 1996 tercatat ada 50 perusahaan asuransi yang berkegiatan dengan pangsa pasar pemegang polis meliputi 7\% seluruh penduduk (saat itu). Krisis ekonomi pada tahun 1998 membuat operasional perusahaan asuransi jiwa juga mengalami banyak kendala. Beberapa perusahaan mengalami penutupan sehingga pada tahun 2006 menjadi 42 perusahaan namun sampai sekarang adanya berbagai masalah keuangan membuat pasang surut jumlah perusahaan asuransi jiwa di Indonesia.

Penilaian kinerja dan kesehatan keuangan perusahaan asuransi jiwa berdasarkan Keputusan Menteri Keuangan Republik Indonesia 481/1999 mempunyai acuan baku dengan orientasi pada kesehatan keuangan yaitu pendekatan kemungkinan likuidasi. Penilaian ini untuk kepentingan pemegang polis supaya tidak dirugikan oleh kinerja keuangan yang buruk. Acuan baku tersebut adalah nilai Risk Based Capital (RBC). Nilai RBC menggambarkan perbandingan risiko usaha perusahaan asuransi jiwa dapat mengalami likuidasi apabila nilai RBC tidak mencapai $120 \%$.

\section{A. Jejaring dan Sumber Daya}

Para ahli organisasi dan sosiologi menyatakan bahwa aspek penting dari berbagai aspek yang ada pada lingkungan organisasi adalah hubungan eksternal dalam jaringan kerja. Jaringan kerja sosial (Social Network) merupakan pandangan hubungan sosial dalam terminologi jaringan. Jaringan kerja merupakan himpunan hubungan antar perusahaan vertikal maupun horizontal, dengan organisasi lain seperti pemasok, pelanggan, pesaing dan entitas lainnya (Gulati, Nohria, \& Zaheer, 2000). Kondisi perusahaan dalam kerjasamanya dengan perusahaan lain mempengaruhi kinerja perusahaan. Semakin berada pada posisi sentral, suatu perusahaan semakin baik kinerja perusahaan. Hal ini karena pada posisi tersebut 
berarti terjadi akumulasi sumber daya (Powell, Koput, Smith-Doerr, \& OwenSmith, 1999).

Secara konsep, jaringan kerja berkaitan dengan sumberdaya relasi dan ada dua hal yang menjadi unsur utama jaringan kerja yaitu peranan (role) dan posisi (position). Pada teori analisis jaringan kerja, terminologi posisi mengacu pada sekumpulan individu yang secara similar tertanam kuat dalam jaringan relasi. Role atau peranan menunjukkan pola relasi yang diperoleh sang actor/pelaku kerja sama oleh karena posisinya dalam jaringan kerja yang ada (Wasserman \& Faust, 2009). Pemahaman mengenai posisi dan peranan ini menyebabkan pengertian suatu pengelompokan pelaku usaha/industri berdasarkan kesamaan aktivitas, ikatan atau kegiatan dengan memperhatikan aktor pelaku yang ada pada posisi lainnya. Hal ini menyebabkan suatu jaringan kerja yang multi relasi, yang mencakup banyak hubungan antara pelaku menjadi sangat bermanfaat untuk dianalisis guna menilai posisi dan peran masing aktor pelaku di antara lainnya. Suatu analisis posisi dan peranan yang komplit akan menghasilkan penentuan/penugasan aktor pelaku pada posisi tertentu dan suatu model dari sistem relasi yang menghubungkan posisi posisi (Wasserman \& Faust, 1994).

Penelitian oleh (Ouimet, Landry, \& Amara, 2004) menghasilkan temuan bahwa posisi kompetitif suatu perusahaan meningkat dengan adanya jaringan kerja industri. Hal ini karena adanya pertukaran pengetahuan antar peserta tersebut. Posisi perusahaan dalam klaster mempengaruhi peningkatan kinerja intelektual. Beberapa penelitian mengidentifikasi adanya hubungan antara kegiatan mikrodinamika dalam klaster dengan kondisi kinerja perusahaan.

Kluster merupakan sekumpulan perusahaan dari suatu industri yang menciptakan pekerjaan menyangkut jasa ataupun pembuatan barang, yang secara bersama mempunyai kebutuhan dasar ekonomi yang sama, yang menyatukan semua anggota kluster dalam komunitas ekonomi. Adanya pembentukan kluster menjadi wadah relasi yang mendasari pembentukan jaringan kerja (Ouimet et al., 2004). Model jaringan merupakan implementasi lubang struktur. Adanya lubang struktur merupakan kekosongan dalam struktur sosial, ada posisi kosong atau kurangnya pelaku. Ketika pelaku industri menempati posisi tersebut, pelaku tersebut terhubung dengan para pelaku lainnya yang sebelumnya tidak terhubungkan. Posisi perusahaan tersebut dalam jaringan kerja sama industri menjadi penentu akses perusahaan terhadap segala peluang bisnis (Muller \& Peres, 2019).

Keuntungan berkaitan dengan posisi dalam jaringan berkaitan dengan perolehan sumber daya. Penelitian oleh (Park, Chen, \& Gallagher, 2002) menunjukkan hal tersebut, perusahaan-perusahaan dengan sumber daya tinggi lebih mudah memperoleh posisi sentral dalam jaringan kerja. Menurut (Marrocu, Usai, \& Paci, 2013), suatu perusahaan dipilih dalam suatu kerja sama karena posisinya dalam jaringan kerja industri. Pada penelitian Usai ini, salah satu faktor yang dapat mempengaruhi posisi perusahaan jaringan kerja adalah teknologi. 
Analisis posisi dan peranan perusahaan sebagai aktor pelaku dalam jaringan berkaitan dengan asosiasi antar peserta jaringan/pelaku lainnya. Adanya relasi menjadi dasar keterkaitan. Bagaimana prosedur keterhubungan antara para pelaku dalam jaringan kerja tersebut, Gambar 1 memperlihatkan urutan pergeseran asosiasi tersebut.

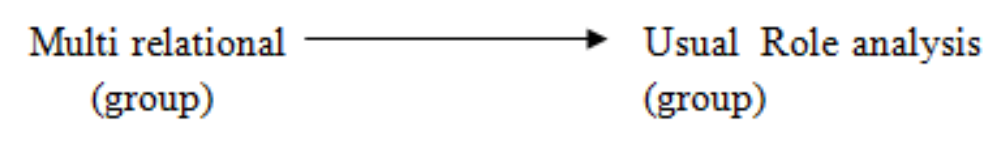

Usual positional $\longrightarrow$ role and positional

(Usai, Maroccu and Paci, 2013)

\section{Gambar 1 \\ Skema Hubungan Posisi dan Peran (Marrocu et al., 2013)}

\section{B. Analisis Kesamaan Struktural}

Suatu analisis menyeluruh dapat dipergunakan untuk mengamati baik posisi maupun peranan namun pada akhirnya lebih banyak dapat dipahami berdasarkan pembentukan struktur jaringan kerja sesuai analisis kesamaan antar para pelaku industri dalam jaringan kerja tersebut. Analisis kesamaan struktur (structurally equivalent analysis) menyatakan bahwa dua actor/pelaku dalam jaringan kerja disebut ekuivalen secara struktural apabila mempunyai ikatan yang identik dari dan ke seluruh aktor pelaku dalam jaringan kerja. Menurut (Wasserman \& Faust, 2009), tujuan utama dari analisis posisi suatu aktor/pelaku dalam konteks jaringan kerjanya adalah untuk menyederhanakan informasi yang dapat diperoleh dalam sekumpulan data jaringan kerja atau kelompok kluster. Penyederhanaan ini mencakup representasi jaringan kerja dalam hal identifikasi posisi, bagaimana posisi tersebut berelasi dengan lainnya, kondisi relasi langsung atau tidak langsung dan bagaimana kohesivitas ikatan relasi yang terbentuk dalam perhubungan antar anggota jaringan kerja industri.

Suatu skema komprehensif mengenai modeling aktor secara individual, peranan dan keterkaitannya dalam grup secara simultan memakai kondisi ego algebra yang terbentuk oleh adanya aljabar dalam struktur yang berkaitan. Skema ini mempunyai dua bagian yaitu yang pertama menjabarkan perspektif aktor individual dengan pengamatan apakah aktor tersebut mempunyai peran atau posisi yang similar dengan aktor lain dalam jaringan kerja, bagian ke dua dari skema ini adalah penghitungan rasio aljabar yang memperlihatkan kekuatan hubungan tersebut.

\section{Metode Penelitian}

\section{A. Obyek Penelitian}

Obyek pengamatan pada penelitian ini adalah industri asuransi jiwa di Indonesia. Perusahaan asuransi jiwa di Indonesia sampai tahun 2019 terdiri dari 53 
perusahaan. Perusahaan perusahaan tersebut mempunyai kondisi yang berbedabeda, salah satunya dapat dibedakan berdasarkan jenis kepemilikan perusahaan. Pengambilan sampel perusahaan sebagai observasi juga memperhitungkan lama usaha beroperasi (minimal 2 tahun), terpilih 40 perusahaan asuransi jiwa untuk dianalisis (Tabel 1).

\section{Tabel 1}

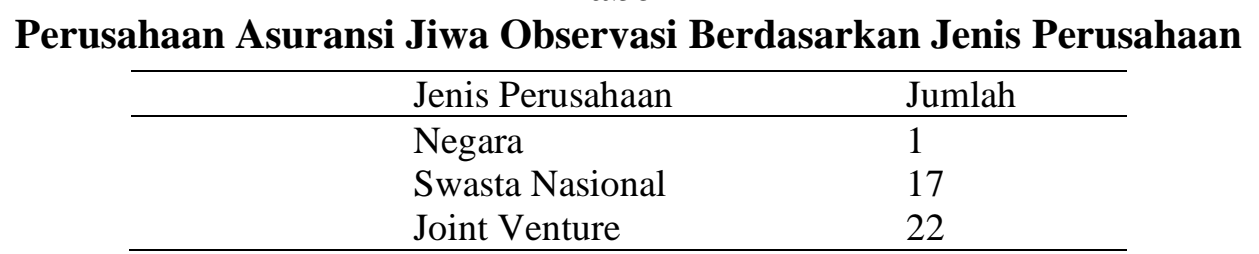

Perusahaan perusahaan asuransi jiwa tersebut tergabung dalam suatu organisasi yaitu Asosisi Asuransi Jiwa Indonesia, dengan demikian perusahaan perusahaan asuransi jiwa tersebut mempunyai dasar untuk membentuk kerja sama karena berada dalam kelompok industri tertentu.

\section{B. Variabel Penelitian}

Pada penelitian ini, similaritas dan ekuivalensi antar perusahaan ditinjau dari enam atribut keuangan perusahaan asuransi jiwa sebagai variabel pengamatan. Atribut - atribut itu:

1. Investasi

2. Asset

3. Modal

4. Premi

5. Hutang

6. Laba

\section{Data}

Penelitian ini mempergunakan data sekunder berupa Laporan Keuangan Perusahaan Asuransi Jiwa periode tahun 2019.

\section{Metode Analisis}

Pada Statistika Multivariat, metode klastering berpera untuk mengadakan pengelompokan data berdasarkan faktor baris/row. Terdapat dua tipe klastering yaitu K-means dan Hirarki. Prinsip sistem klastering ini adalah pengelompokan berdasarkan jarak dengan pusat.

Pada penelitian ini, pengelompokan perusahaan perusahaan asuransi jiwa dengan metode klastering hirarki untuk memperoleh hasil pengelompokan yang lebih alamiah terhadap variabel investasi, premi, laba, hutang, modal dan laba.

\section{Hasil dan Pembahasan}

\section{A. Structural Equivalence antar Data}

Istilah structural equivalence mulai dikenal sejak tahun 1970an. Istilah ini mengacu pada property matematik bagian himpunan (subset) para pelaku dalam jaringan kerja atau nodes dalam graf. Ringkasnya, dua aktor pelaku disebut 
ekuivalen secara struktural bila mempunyai ikatan yang identik, dari dan ke aktoraktor atau pelaku lain dalam jaringan kerja. Sekumpulan aktor-aktor pelaku yang mempunyai ekuivalensi struktural akan dikelompokkan dalam kelas ekuivalensi atau berarti pada posisi tertentu. Jika aktor i dan j secara struktur terhitung ekuivalen (三) maka keduanya berada pada posisi yang sama. Apabila dua aktor pelaku bersifat ekuvalen maka keduanya mempunyai baris dan kolom sociomatrix yang sama sehingga keduanya dapat saling bergantikan (substitutable).

Penentuan ekuivalensi sehingga dapat memasukkan para pelaku dalam kelas ekuivalensi yang sama merupakan langkah awal dalam analisis posisi. Hal ini merupakan upaya partisi himpunan yang merupakan kumpulan pelaku / aktor dalam industri yang diamati. Langkah selanjutnya meliputi:

a) Pengukuran derajat hubungan: ikatan yang terjadi antara dua perusahaan atau aktor dalam jaringan kerja memperlihatkan hubungan antara perusahaan perusahaan tersebut. Kekuatan hubungan ini digambarkan oleh multidimensional scalling yang menunjukkan arah hubungan, masuk (indegree) atau keluar (outdegree).

b) Pernyataan adanya ekuivalensi: apabila kondisi suatu aktor atau pelaku dibandingkan dengan pelaku yang lain dan didapatkan adanya kesamaan atau ekuivalen pada beberapa aspek maka aktor aktor yang notabene perusahaan tersebut dikelompokkan pada lokus yang sama.

Langkah terakhir dalam analisis posisi yaitu pernyataan bagaimana posisi antar pelaku atau aktor berhubungan / berelasi satu sama lain. Hal ini akan menghasilkan adanya kesimpulan peran tertentu bagi masing masing pelaku. Tujuan utama dari tampilan ini adalah untuk menghasilkan informasi dalam kumpulan data dengan format lebih sederhana dan memperoleh interpretasi tertentu sebagai kesimpulan akhir .

\section{B. Data}

Pada penelitian upaya pengelompokan perusahaan perusahaan asuransi jiwa berdasarkan atribut keuangan ini, variabel yang dipergunakan meliputi besaran investasi, premi, asset, modal, hutang dan laba perusahaan-perusahaan asuransi jiwa Indonesia. Berdasarkan Laporan Keuangan Perusahaan Perusahaan Asuransi Jiwa Indonesia maka atribut keuangan perusahaan asuransi pada periode tahun 2019 untuk variabel - variabel yang menjadi bahan perbandingan obyek adalah terlihat pada tabel 2: 
Tabel 2

Data Keuangan Perusahaan Asuransi Jiwa yang diobservasi (dalam milyar rupiah)

\begin{tabular}{lllllll}
\hline Perusahaan & Invest. & Asset & Modal & Premi & Hutang & Laba \\
\hline AJB.BP & 10048 & 21488 & 183 & 5069 & 699 & 82 \\
Cigna & 1419 & 1578 & 20 & 1197 & 98 & 224 \\
In Health & 1213 & 1452 & 1000 & 1073 & 35 & 47 \\
Indolife & 8410 & 8804 & 122 & 5479 & 13 & 139 \\
Simas & 21175 & 21572 & 105 & 12488 & 264 & 1293 \\
Adi SW & 1974 & 2310 & 322 & 3117 & 93 & 147 \\
Axa & 10067 & 11593 & 101 & 4851 & 785 & 1121 \\
Allianz & 14873 & 15503 & 519 & 6781 & 1050 & 363 \\
Manulife & 21988 & 23526 & 4452 & 7123 & 708 & 448 \\
Prudential & 27462 & 39059 & 4334 & 14312 & 2498 & 3726 \\
BRI & 2294 & 2707 & 482 & 1530 & 111 & 139 \\
Jiwasraya & 7442 & 8002 & 1395 & 4763 & 183 & 394 \\
AIA & 21606 & 22723 & 4529 & 4359 & 1116 & 466 \\
Comm & 3842 & 3991 & 693 & 1212 & 149 & 202 \\
Sequis & 7142 & 7410 & 1041 & 1723 & 256 & 231 \\
Mega & 2768 & 3044 & 405 & 5213 & 57 & 50 \\
Avrist & 10117 & 10407 & 1976 & 1341 & 855 & 281 \\
BNI & 2405 & 2521 & 180 & 1074 & 81 & 2 \\
AxaFin & 2617 & 2860 & 247 & 1066 & 195 & 38 \\
Panin & 3516 & 3640 & 337 & 2449 & 82 & 76 \\
SunLife & 4648 & 4805 & 937 & 867 & 218 & 102 \\
CAR & 3154 & 3322 & 964 & 630 & 199 & 118 \\
Equity & 1436 & 1565 & 135 & 740 & 63 & 22 \\
CIMB & 1089 & 1122 & 97 & 943 & 44 & -42 \\
Great East & 1490 & 1612 & 463 & 777 & 130 & 38 \\
Tugu & 362 & 390 & 87 & 188 & 16 & 26 \\
ACE & 329 & 425 & 121 & 346 & 77 & -41 \\
Recapita & 139 & 91 & 231 & 346 & 14 & 26 \\
SequisFin & 392 & 417 & 216 & 29 & 19 & 23 \\
Axalife & 1840 & 1976 & 592 & 172 & 72 & 23 \\
MAA & 76 & 15 & 4 & 44 & 19 & -22 \\
Zurich & 75 & 91 & 70 & 6 & 19 & -59 \\
Pasaraya & 64 & 72 & 44 & 20 & 1 & 1 \\
Nusantara & 267 & 409 & 131 & 20 & 29 & 3 \\
Multicorp & 39 & 53 & 44 & 8 & 1 & 1 \\
MNC & 78 & 99 & 49 & 55 & 9 & -17 \\
Kresna & 102 & 121 & 62 & 98 & 8 & 1 \\
Heksa & 105 & 175 & 65 & 278 & 15 & 8 \\
Generali & 304 & 396 & 76 & 315 & 85 & -32 \\
Aviva & 263 & 409 & 110 & 611 & 93 & -40 \\
\hline \multicolumn{1}{c}{ (Sumber: Laporan Keuangan Asuransi Jiwa Indonesia) } \\
& & & & & &
\end{tabular}

Data keuangan perusahaan asuransi jiwa di Indonesia tersebut (tabel 2) menunjukkan keragaman kondisi antar perusahaan perusahaan asuransi jiwa di Indonesia. Pada kesemua atribut keuangan yang diamati, terlihat nilai range yang lebar. Atribut investasi berada pada range antara 39 sampai 21988 (Rp M) 
demikian juga untuk asset, modal dan premi. Hal ini menyebabkan kinerja perusahaan juga berbeda. Beberapa perusahaan pada posisi kerugian (laba negatif).

\section{Klastering}

Penentuan posisi perusahaan perusahaan asuransi jiwa Indonesia berdasarkan ke enam atribut keuangan yaitu nilai investasi, asset, modal, premi, hutang dan laba tersebut dengan mempergunakan analisis klaster metode hirarki. Metode hirarki memungkinkan terjadi pengelompokan yang lebih alamiah karena pembandingan jarak antar perusahaan dengan metode Euclidean.

Analisis dilakukan terhadap data keuangan 40 perusahaan asuransi jiwa Indonesia dengan alat SPSS 22. Pengelompokan yang terjadi menurut alat analisis tersebut adalah:

\section{Tabel 3}

Pengelompokan /Klastering Perusahaan Asuransi Jiwa

\begin{tabular}{cl}
\hline Kluster A & AJBP, Cigna, Indolife, InHealth, Adi SW, Axa, Allianz, BRI, \\
(36 perus.) & Jiwasraya, Commonwealth, Mega, Avrist, BNI, AxaFin, Panin, SUN, \\
& CAR, Equity, CIMB, Great Eastern, Tugu, ACE, Recapita, Squis Fin, \\
& Axalife, MAA, Zurich, Pasaraya, Nusantara, Multicorp, MNC, \\
& Kresna, Heksa Life, Generali, Aviva, Sequis Life \\
\hline Kluster B & Simas, AIA, Manulife \\
(3 perus.) & \\
\hline $\begin{array}{l}\text { Kluster C } \\
\text { (1 perus.) }\end{array}$ & Prudential \\
\hline
\end{tabular}

Tabel 3 tersebut menunjukkan posisi perusahaan perushaan asuransi jiwa dan menunjukkan peluang hubungan kerja sama antar perusahaan. Pada klaster A terdapat 36 perusahaan yang relatif menempati locus atau posisi yang sama (kita sebut posisi A), sebanyak tiga perusahaan pada locus B dan satu perusahaan menyendiri di locus $C$. Penyebaran perusahaan-perusahaan asuransi jiwa Indonesia yang sedemikian rupa tersebut memperlihatkan bahwa kondisi sumber daya perusahaan perusahaan asuransi jiwa di Indonesia tergolong homogen, Hal ini terlihat dari structural equivalence nya, terjadi pengelompokan $70 \%$ dari seluruh perusahaan berada pada lokasi yang sama.

\section{Analisis Posisi dan Peran}

Perusahaan yang berada pada posisi sama lebih mudah melakukan relasi atau kerja sama antar keduanya. Perusahaan - perusahaan asuransi jiwa pada locus A lebih mungkin melakukan kerja sama satu sama lain untuk memperoleh sumber daya lebih baik. Perusahaan yang berada pada locus A tergolong mayoritas (70 \%) sedangkan perusahaan - perusahaan yang menempati locus B hanya 3 perusahaan dan locus $C$ hanya satu perusahaan. Penentuan posisi semacam itu berarti ikatan ikatan dalam kelompok yang sama juga bersifat sama. Setiap ikatan, baik ikatan ke luar maupun ke dalam. Ikatan ikatan inilah yang menyebabkan suatu perusahaan dapat mempunyai peran dalam hubungannya dengan aktor/ perusahaan lain. 
Apabila beberapa perusahaan dalam locus A saling mengadakan kerja sama kemudian salah satu dari perusahaan tersebut mengadakan kerja sama dengan perusahaan di locus B atau C, maka perusahaan pelaku kerja sama tersebut berperan menjadi perantara sumber daya (antara locus A dan locus B).

Secara teori sosial, peran atau role sering dinyatakan sebagai kemilikan individu atau sekumpulan individu sehingga peran - peran yang timbul dapat dibawakan oleh satu atau beberapa perusahaan dalam hal ini perusahaan asuransi jiwa. Beberapa perusahaan asuransi yang tergabung dalam suatu kelompok dapat berperan menjadi pengantara antar locus dan mempermudah pengaliran informasi.

Terbatasnya sumber daya modal dan informasi mendorong beberapa perusahaan asuransi untuk melakukan kongsi kerja sama dalam penanggungan risiko. Pada faktanya, beberapa perusahaan yang berada pada posisi locus yang sama (locus A) telah mengadakan kerja sama dalam upaya mengatasi masalah permodalan sehingga dapat memenuhi retensi asuransi yang lebih tinggi, demikian juga beberapa perusahaan mengadakan ikatan dyadic (relasi / kerja sama antara dua perusahaan) untuk membagikan kemampuan informasi dan manajemen mereka seperti kerja sama yang terjadi antar BNI Life dan Cigna. Perusahaan BNI Life dengan kemampuan informasi dan data memperoleh bagian ketrampilan agen dari Cigna.

\section{Kesimpulan}

Pada saat ini, suatu aspek terpenting dalam lingkungan organisasi adalah hubungan eksternal dalam suatu sistem relasi yang disebut modal relasi. Jejaring kerja (Social Network) dalam konteks hubungan antar perusahaan menjadi jejaring organisasi (Organizational Network Analysis). Peluang kedekatan antar perusahaan menjadi hal yang penting untuk menilai kemungkinan terjadinya kerjasama antar perusahaan.

Analisis klaster hirarki tepat dipergunakan pada upaya penilaian peluang kerja sama antara perusahaan asuransi jiwa di Indonesia karena mempunyai sistem perbandingan lebih alamiah. Berdasarkan atribut atribut keuangan yang dipunyainya, perusahaan perusahaan asuransi jiwa di Indonesia dapat dikelompokkan dalam tiga locus yang menunjukkan posisi mereka. Posisi perusahaan perusahaan tersebut cenderung memperlihatkan kondisi mayoritas pada suatu locus tertentu karena dari sebanyak 40 perusahaan asuransi jiwa, 36 perusahaan berkumpul pada locus yang sama. Hal ini menggambarkan homogenitas kondisi jejaring asuransi jiwa di Indonesia. Perusahaan perusahaan yang berada pada locus yang sama cenderung lebih mudah mengadakan jalinan kerja sama dibandingkan dengan perusahaan pada locus yang berbeda.

Kekuatan kerja sama perusahaan akan menunjukkan bagaimana peranan (role) perusahaan tersebut dalam relasinya dengan perusahaan lain. 


\section{BIBLIOGRAFI}

David, Fred R., Ali, Abbas J., \& Al-Aali, Abdulrahman Y. (2009). Strategic management: Concepts and cases. Google Scholar

Feser, Edward J., \& Bergman, Edward M. (2000). National industry cluster templates: A framework for applied regional cluster analysis. Regional Studies, 34(1), 1-19. Google Scholar

Gulati, Ranjay. (1999). Network location and learning: The influence of network resources and firm capabilities on alliance formation. Strategic Management Journal, 20(5), 397-420. Google Scholar

Gulati, Ranjay, Nohria, Nitin, \& Zaheer, Akbar. (2000). Strategic networks. Strategic Management Journal, 21(3), 203-215. Google Scholar

Marrocu, Emanuela, Usai, Stefano, \& Paci, Raffaele. (2013). Networks, proximities and inter-firm knowledge exchanges. Centre for North South Economic Research, University of Cagliari and Sassari .... Google Scholar

Muller, Eitan, \& Peres, Renana. (2019). The effect of social networks structure on innovation performance: A review and directions for research. International Journal of Research in Marketing, 36(1), 3-19. Google Scholar

Ouimet, Mathieu, Landry, Réjean, \& Amara, Nabil. (2004). Network positions and radical innovation: a social network analysis of the Quebec optics and photonics cluster. DRUID Summer Conference, 14-16. Citeseer. Google Scholar

Park, Seung Ho, Chen, Roger, \& Gallagher, Scott. (2002). Firm resources as moderators of the relationship between market growth and strategic alliances in semiconductor start-ups. Academy of Management Journal, 45(3), 527-545. Google Scholar

Powell, Walter W., Koput, Kenneth W., Smith-Doerr, Laurel, \& Owen-Smith, Jason. (1999). Network position and firm performance: Organizational returns to collaboration in the biotechnology industry. Research in the Sociology of Organizations, 16(1), 129-159. Google Scholar

Wasserman, Stanley, \& Faust, Katherine. (1994). Social network analysis: Methods and applications. Google Scholar

Wasserman, Stanley, \& Faust, Katherine. (2009). Social network analysis: Methods and applications. Google Scholar 
Titiek Irewati

Copyright holder:

Titiek Irewati (2022)

First publication right:

Syntax Literate: Jurnal Ilmiah Indonesia

This article is licensed under:

(c) (i) (D) 